\title{
単音節明暸度試験法による帯域騒音及び聴力損失が 音声情報伝達に及ぼす影響の評価について
EVALUATION OF EFFECT OF HEARING LOSS ON SPEECH INTELLIGIBILITY BY MONO-SYLLABLE ARTICULATION TEST UNDER SOUND FIELDS WITH $1 / 1$ OCTAVE BAND NOISE

\author{
佐藤 洋*, 長友宗重**, 吉野 博*** \\ Hiroshi SATO, Muneshige NAGATOMO and Hiroshi YOSHINO
}

\begin{abstract}
The purpose of this paper is to observe the difference in hearing ability between normal hearing and impaired hearing for the parameters of $\mathrm{AI}$, and to know the effects of frequency characteristic of masking noise on syllable perception. This study includes the articulation tests and determines AI of the experiment sound fields by varying its parameters.

The results of articulation test indicate that the effect of $\mathrm{S} / \mathrm{N}$ on speech discrimination is different in each octave band noise, and the difference of articulation score between normal hearing and impaired hearing becomes larger in 0.5 or $1[\mathrm{kHz}]$ band. As a result of considering hearing loss in AI calculation, it is able to reflect hearing ability by optimizing its parameters. And considering syllable appearance in sentences, it is limited to the use of syllables of highest impact.
\end{abstract}

Keywords: $\quad$ syllable articulation, presbycusis, band noise, articulation index 音節明暸度, 老人性難聴, 帯域騒音, 明睹度指数

1.はじめに

近年, 高齢社会を迎え, 公共空間の利用者に高秢者の割合が増加 しているため, 公共放送等の音声情報伝達を行う際に聴力損失をと もなう高歯者に対する配慮が欠かせない。そのため, 騒音や残響と いった空間内の音声聴取上の妨害因子が, 聴力損失を伴った受聴者 が音声を聴取する際にどのような影響を及ぼすかを定量的に把握す る必要がある。

聴力損失が音声伝達に及ほす影響に関して, Pavlovicらは, 限定 された条件下ではあるが，聴力レベルの特性を考慮することにより AI (Articulation Index) $)^{1)}$ によって, 音声聴取状況の予測が可能で あると報告している2゙3)。また, 坂田らは, 明瞭度と損失情報量の観 点から, 聴力損失は音声伝達に対する影響は大きいと報告しており 4)，落合らは，4kHzに拈ける聴力レベルと音節明瞭度の関係を環境 音の有無により比較し, 聴力レベルが大きくなるにつれて環境音の 影響が大きくなると報告している5)。

また, 音源系の検討に関しては, 音声情報の内容として, 文章中 の音節出現率に関する検討が行われており, 出現頻度で重みづけを 行った明瞭度試験用音表を用いた結果, 飯田 ${ }^{6}$, 山田》は大きな違い はないと報告している。一方，坂田らは平等率音表の結果からシ ミュレーションを行い, 出現頻度の影響は大きいと報告している4。
以上のことから,本研究では実験室内に打ける1/1オクターブ帯域 騒音付加音場を用い，単音節明瞭度試験実験8) 9)により騒音の带域 及び聴力損失の音声情報伝達への関与の仕方を実験的に調べる。ま た，騒音が音声情報伝達に与える影響を，聴力損失を考慮したうえ で定量的に評価するため，AIを評価指標として用い，AIのパラメー 夕を最適化し，聴力損失を考慮するための検討を行う。さらに，騒 音場における発声音節の受聴状況と文中の音節出現頻度から, 音声 情報伝達を行う上で, 健聴者及び高齢者にとって重要な異聴を抽出 することにより，音声情報伝達時に考慮すべき音節を示し，非常放 送等の音源デザインを行う際の基礎資料を提供する。

\section{2. 各帯域騒音付加音場における単音節明瞭度試験実験 \\ 2.1 実験音場}

実験は東北大学工学部建築学科の簡易無響室内において行った。 実験系のブロックダイアグラムを図 1 に示す。試験用音源は音源用 スピーカーから, 付加騒音は音源スピーカーの両脇に配置した騒音 用スピーカーから各条件ごとに表 1 に示すレベルで提示した。なお， 音源の提示レベルは被験者の耳元に扔ける各音節のピークレベル平 均 (時定数:Fast) である。実験に用いた騒音の $1 / 3$ オクターブバン ドレベルを図 2 に示す。

\footnotetext{
* 東北大学工学部建築学科 助手 $\cdot$ 工修

** 鹿島建設株式会社 工博

*** 東北大学工学部建築学科 教授. 工博
}

Research Assoc., Dept. of Architecture, Faculty of Engineering, Tohoku Univ., M. Eng.

Kajima Corpolation, Dr. Eng.

Prof., Dept. of Architecture, Faculty of Engineering, Tohoku Univ., Dr. Eng. 


\section{2 実験用音源}

音源は, 日本音響コンサルタント協会編, 単音節明瞭度試験用音源 テープ (1979 年版, 男声) を用いた9)。

\section{3 被倹者及び音表数}

被験者には聴力検查の結果, 聴力健常と認められた 20 歳代の学生 (以下健聴者) を 19 名, 及び加齢による聴力損失を持つ50〜70歳代 の者 (以下高龄者) を 13 名用いた。また，各条件毎の平均音表数は 健聴者群については32音表, 高齢者群については18音表である。各 被験者群の平均聴力レベル及びその標準偏差を図 3 に示す。高齢者 の聴力のばらつきはISO7029-1984 (E) ${ }^{10)}$ に示されている通り非常 に大きいことがかかる。

\section{4 各帯域騒音の SN 比と単音節明瞭度}

図 4 に各帯域騒音付加音場における SN 比と単音節明瞭度の平均 值・標準偏差を示す。特徵として以下の点があげられる。(1)低い周 波数帯域 $(500 \mathrm{~Hz}, 1 \mathrm{kHz})$ の騒音場においては SN 比の悪化に伴い 明瞭度が急激に下降し始める点がみられる。(2)高い周波数帯域 $(2 \mathrm{kHz}, 4 \mathrm{kHz})$ の付加騒音場においては SNに対する明瞭度の変化 は緩やかである。(3) $500,1 \mathrm{kHz}$ 帯域騒音付加音場において，明瞭度 が急激に下降し始める点以降，及びその他の音場では，両被験者群 を比較するとその傾向は類似している。

また, 高龄者が健聴者と同程度の明瞭度を得るには, SN比におい

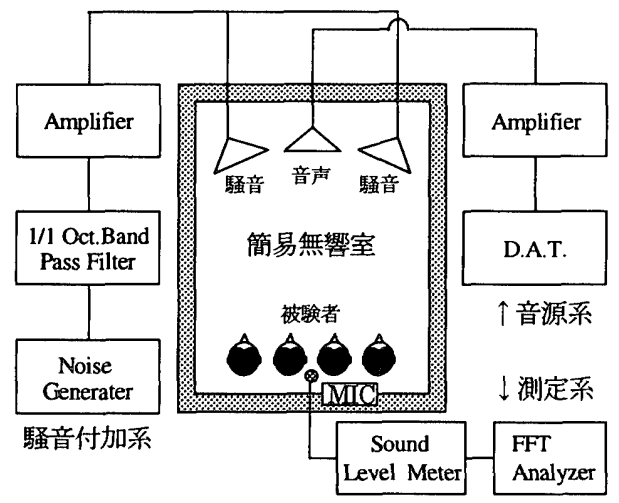

図 1 実験系ブロックダイアグラム

表 1 各 SN 比条件における音源・騒音の提示レベル

\begin{tabular}{crrrrr}
\hline SN比 & 0 & -10 & -15 & -20 & -25 \\
\hline 音源レベル & 60 & 60 & 55 & 50 & 45 \\
馶音レベル & 60 & 70 & 70 & 70 & 70 \\
\hline
\end{tabular}
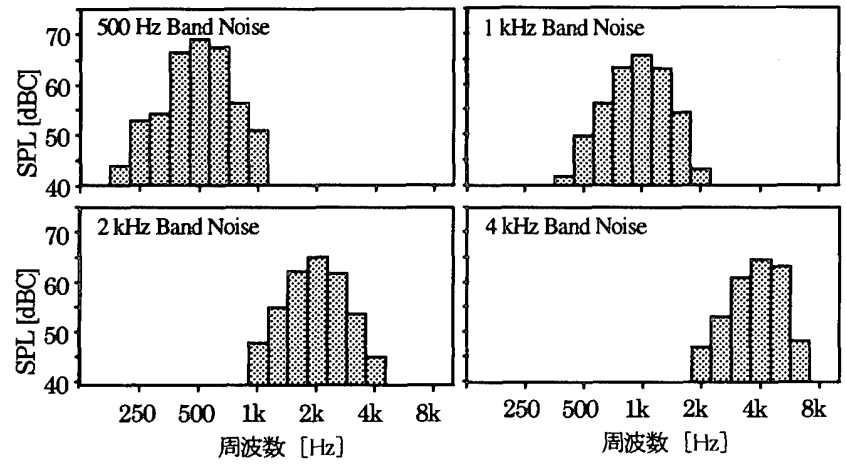

図 2 付加騒音の $1 / 3$ オクターブバンドレベル
て5〜10dBAの改善が必要である。500Hz帯域騒音場における明瞭 度の急激な下降は，母音の正聴率の急激な下降と対応しており，こ の帯域においては母音の識別が明瞭度に与える影響が大きいことを 示している。

高齢者の明瞭度は, $500,1 \mathrm{kHz}$ の騒音が付加された場合にばらつ きが大きくなり，かつ健聴者との差む大きい。これは被験者間の聴 力のばらつき及び健聴者と高齢者の聴力差が小さいこと, 低い周波 数帯域が騒音により妨害された場合, 音節の受聴は被験者間のばら つきが大きく，聴力損失の程度も大きい高い周波数域の聴力に依存 するためである。

\section{3. 単音節明瞭度と明瞭度指数}

音場評価の際の物理的側面から，聴力損失を考慮する場合につい て明瞭度指数による検討を行った。

\section{1 明瞭度指数の算定手続き}

本節において，明瞭度指数は ANSI ${ }^{1)}$ の新 $1 / 1$ オクターブバンド法 を基本とし， STI (Speech Transmission Index) 算出における手続

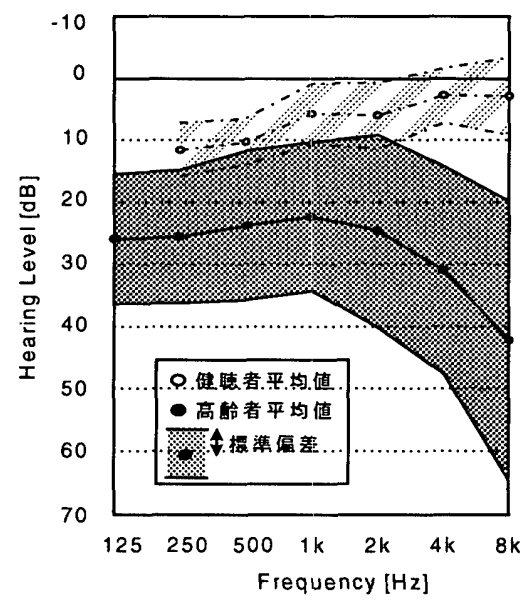

図 3 被験者群の平均聴力レベル
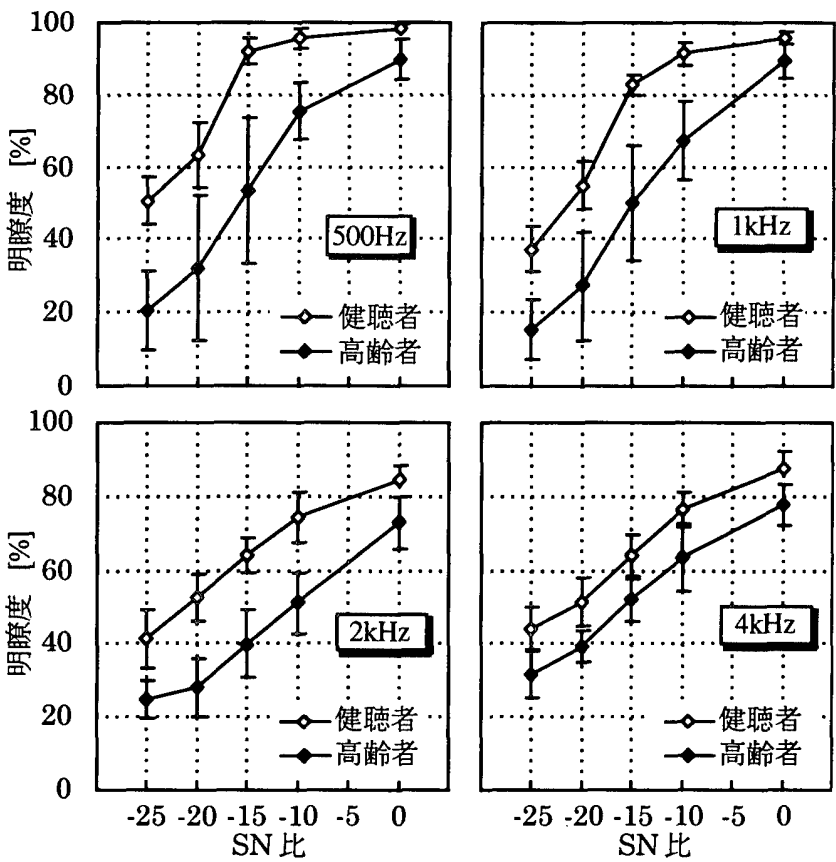

図 4 各帯域騒音付加音場における健聴者と高齢者の単音節明暸度 
き11) 12) を参考として，式 (1) 〜 (3) のように扱う。

$$
\begin{aligned}
& S N R_{k}=L_{S k}-L_{N k} \quad \cdots \cdot(1) \\
& T I_{k}=\left(S N R_{k}-S\right) / R \quad \cdots(2) \\
& A I=\sum W_{k} \cdot T I_{k}
\end{aligned}
$$

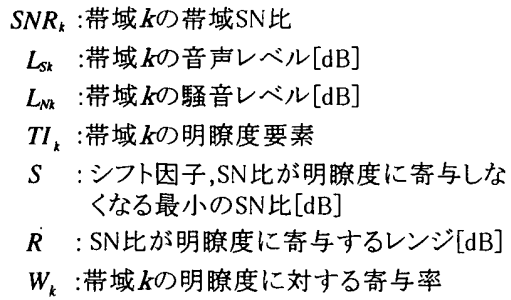

式 (2) におけるシフト因子 $\mathrm{S}$ とレンジ Rについて，概念図を図 5 に示す。ANSI の基準では, 式 (2) のシフト因子 Sがゼロとなって いるが, 前節の結果から, SN 比がゼロ以下の条件においても， SN 比が音節明瞭度に関係していることから，シフト因子Sについての 検討が必要となる。また，レンジRについては，ANSIにおいては $\mathrm{R}=30$ となっているが, 本報では，電話伝送系における結果ではある が，日本語に関して求められた三浦による $\mathrm{R}=35$ を用いる ${ }^{12) 。 ~}$

\section{2 最小可德音声レベルの測定によるシフト因子Sの導出}

本報ではSN比が明瞭度に寄与しなくなる最小のSN比を，ある騷 音条件と最小可聴音声レベルの SN 比と同義と仮定し, 実験的にシ フト因子 $\mathrm{S}$ を求めた。実験は図 6 に示した系を用いて行った。音源 として，図 7 に示した特性を持つ継続時間 4 秒の男声アナウンスを, 騷音として音声と同じ特性を持つ定常騒音を用いた。明瞭度試験に おいて用いた音場は帯域制限された騒音を用いた音場であったが， ここでは，AIやSTIを算出する際に， S を全ての周波数帯域につい て共通に用いていることから，本検討ではマスキングの効果を大き く保つために音声と同様の周波数特性を持つ広帯域騒音を用いた。 騒音のレベルは $50,60 ， 70,80[\mathrm{dBC}]$ 注1) の 4 条件とし, 被験者に ランダムに 3 回提示し，それぞれのレベルの騒音下で音声が丁度聞 き取れなくなるレベルに被験者自身が調整し，音声の提示時間平均 レベルを測定した。なお，音声の提示時間平均レベルとピークレベ ル (時定数:Fast) の関係はあらかじめ求めておき，本報における結 果の提示はピークレベルによるものとする。被験者として健聴者 9 名，高齢者 14 名を用いた。なお，健聴者は全て，高齢者は7名を第
2 章において用いた明瞭度試験実験の被験者と重複して用いた。

各ノイズレベルにおける最小可聴音声レベルの平均值とノイズレ ベルとのSN比を図8に示す。ノイズレベルの上昇に伴いSN比は低 くなる。このことはSがノイズレベルにより変化することを示して いる。この結果は電話伝送系における三浦の結果 ${ }^{13)}$ と異なっており， 伝送系の違いによるものと考えられる。SN比について，健聴者群と 高齢者群で差が生じているのは，高齢者群の最小可聴値が聴力損失 により低下しているためである。また，騒音レベルが増加するにし たがって SN 比が低下する理由としては，騒音と音源のスピーカー が異なるため, 音源と騒音の到来方向が異なり，音源を騒音下から 抽出しやすいことが一因となっていると推察でき，抽出しやすさの 程度は健聴者の方が高いことがあげられる。この結果より，以後の $\mathrm{AI}$ の検討には明瞭度試験実験における騒音レベル $60 \mathrm{dBA}$ の条件 ( $\mathrm{SN}$ 比 $0 \mathrm{~dB}$ の条件) に関しては $\mathrm{S}=-12.9$ (健聴者), $\mathrm{S}=-10.1$ (高 齢者)を，騒音レベル 70dBAの条件 ( $\mathrm{SN}$ 比 $0 \mathrm{~dB}$ 以外の条件) 関して は $\mathrm{S}=-15.8$ (健聴者), $\mathrm{S}=-12.2$ (高龄者) を用いる。

\section{3 単音節明瞭度と明瞭度指数の関係}

第 2 章で行った明瞭度試験実験の結果とパラメータを変化させた 明瞭度指数の関係を図 9 に示す。図 9 の曲線は健聴者について三浦 により 13) 求められたものである。明瞭度指数をANSI の基準と同様 に S=0 とし，Wk についても ANSI の基準と同様にして算出した場 合，健聴者と高齢者の対応はとれず，また三浦による予測曲線との 対応も良くない。4.2節で求めたシフト因子Sを用いて明瞭度指数を 算出した場合，三浦による予測曲線との対応はよくなり，重相関係 数は 0.88 となった。これより，明瞭度指数による音声伝達性能評価 の際には，シフト因 $\mathrm{S}$ の調整により加齢による聴力損失を考慮で きることが示された。

さらにWk を被験者群ごとに三浦による予測曲線に当てはめるこ とを試みた。その結果, 表 2 に示したパラメータを用いた場合, 重 相関係数は 0.97 となり, 非常に 対応が良くなった。Wkは, 健聴 者については $1 \mathrm{kHz}$ 带域を境に 周波数が高くなるにつれて大き くなっていることがわかる。こ れは健聴者が母音を異聴しにく いことから，母音が優勢な帯域 の寄与が小さくなった結果と捉 えることができる。高齢者につ

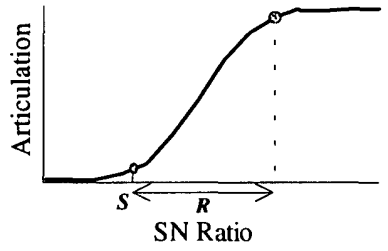

図 5 シフト因子 Sとレンジ $R$ の概念沤

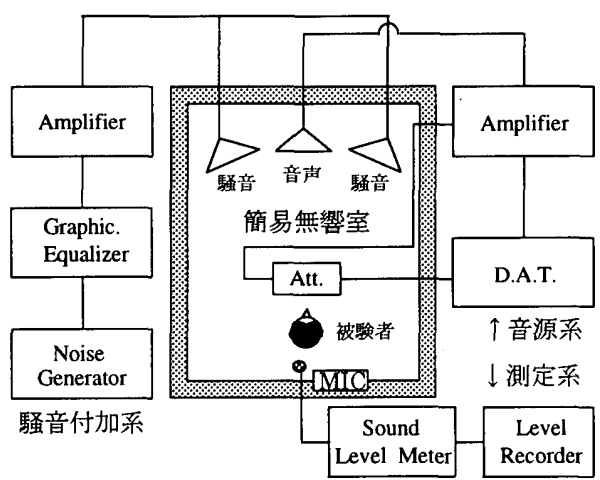

図 6
最小可聴音声レベル測定実験ブロック ダイアグラム

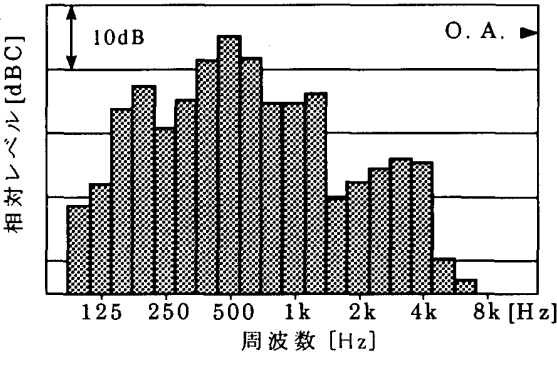

図 7 音声及び定常騒音の $1 / 3$ オクターブ バンドレベル

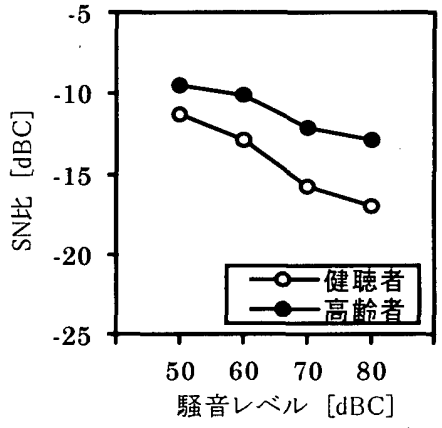

図 8 各騒音レベルにおける最小可 聴音声レベルと騒音レベルの 比 (SN 比) 
いては, $4 \mathrm{kHz}$ 帯域の寄与が大 きく，子音の異聴が支配的で あると考えることができる。

\section{4. 健聴者と高齢者の異聴傾向 の比較}

音声による情報伝達を考え た場合，異聴の起こりやすい 音節をなるべく避け, 音源デ ザインを行うことにより，よ り確実な情報伝達を行うこと ができる。そのためには，音節 の受聴傾向を把握する必要が
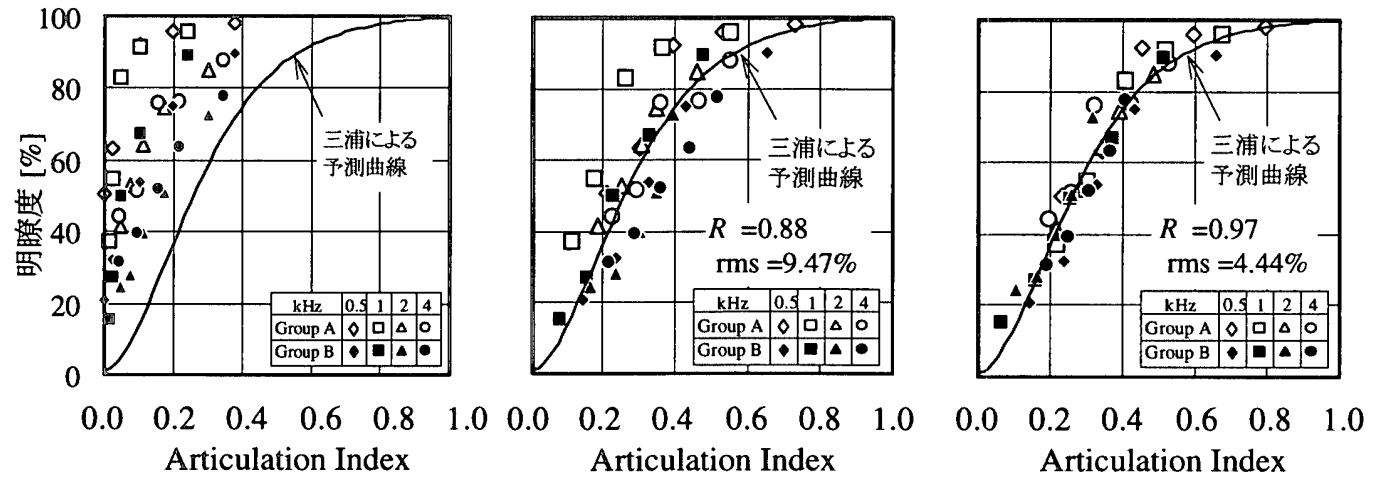

1) ANSIのパラメータを用いた場合 2) 実験で求めたSを用いた場合 3) Wk 最適化した場合

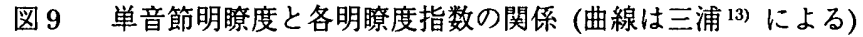

あり，特に聴力損失をもつ高齢者と健聴者の差を把握 することが重要となる。そこで，本節では健聴者と高 齢者の音節異聴の差異について,2節で行った明瞭度試 験実験の結果を用い, 子音の異聴傾向によりその特徵 を明らかにする。なお，健聴者については母音の異聴 はほとんど起こらなかった。図10に健聴者と高齢者の 子音毎の正聴率 (子音明瞭度注2) の関係を各帯域騷音場 毎に SN 比がー $20 \mathrm{~dB}$ の条件について示す。その結果, 以下の特徵が観察される。

(1) 母音/ $/$ の異聴は, $500 \mathrm{~Hz}$ で起こり，健聴者 $72 \%$, 高 齢者 $38 \%$ である。 $1 \mathrm{kHz}$ 以上は者ほほ同様であり，健 聴者は 80～90\%，高齢者は 60～80\%である。

(2)/W/の異聴が $500 \mathrm{~Hz}$ 帯域において，特に健聴者に起 こる。

(3) /R/はいずれの帯域でも高齢者の方が正聴率が高い。 (4)/Ch/, /Ts/の破擦音は健聴者では異聴が起こらない が，高踰者では $40 \sim 60 \%$ の異聴がおこる。 $2 \mathrm{kHz}$ まで は同様の傾向であるが, $4 \mathrm{kHz}$ では健聴者における/Ch/ の異聴が増加し，高齢者と同等の正聴率である。

(5) 破裂音については, /P/の高齢者群における正聴率は ほほゼロに近いが，その他の破裂音については，500， $1 \mathrm{kHz}$ 帯域では，健聴者で約 $50 \%$ ，高齢者で約 $20 \%$ の 正聴率である。 $2 \mathrm{kHz}$ になると, 無声破裂音の健聴者の 正聴率が低下寸る。有声破裂音は健聴者・高齢者とも 正聴率が増加し, $4 \mathrm{kHz}$ になると, 健聴者で $70 \%$, 高齢 者で $45 \%$ 程度の正聴率まで上がる。これより, 高齢者 は無声破裂音を正聴しにくいが, 有声破裂音はノイズ の周波数が上がるにつれて健聴者と同様に正聴率が上 がり，4kHzでは $40 \%$ 以上となる。

(6) $/ \mathrm{M} /, \mathrm{N} /$ の番濁音, / $\mathrm{H} /(500 \mathrm{~Hz}$ 帯域を除く)の正 聴率は健聴者, 高齢者の間に大きな差はない。1 $1 \mathrm{kHz}$ 帯 域で/N/の正聴率が低下する。

(7)/S/, /Z/の有声摩擦音は $2 \mathrm{kHz}$ 以下では健聴者は異聴しにくく, 高 齢者は 40～50\%の正聴率である。しかし， $4 \mathrm{kHz}$ 以上では健聴者も 高齢者と同等の正聴率である。

以上の特徵をふまえ，音源情報のデザインを行うことにより，聴 力損失を考慮した, より確実な情報伝達が可能となる。
表 2 明瞭度指数算出に用いた各パラメータ (ANSI ${ }^{4)}$, 本実験における最適值)

\begin{tabular}{|c|c|c|c|c|c||c||c|}
\hline \multirow{2}{*}{$\mathrm{AI}$ パラメータ } & \multicolumn{5}{|c||}{ 重みづけ係数 } & S & $\mathrm{R}$ \\
\cline { 2 - 7 } & $250 \mathrm{~Hz}$ & $500 \mathrm{~Hz}$ & $1 \mathrm{kHz}$ & $2 \mathrm{kHz}$ & $4 \mathrm{kHz}$ & $70 / 60$ & \\
\hline ANSI & 0.07 & 0.14 & 0.22 & 0.33 & 0.23 & 0 & 30 \\
\hline 健聴者 & 0.22 & 0.12 & 0.11 & 0.27 & 0.28 & $-15.8 /-12.9$ & 35 \\
\hline 高路者 & 0.00 & 0.10 & 0.25 & 0.17 & 0.47 & $-12.2 /-10.1$ & 35 \\
\hline
\end{tabular}
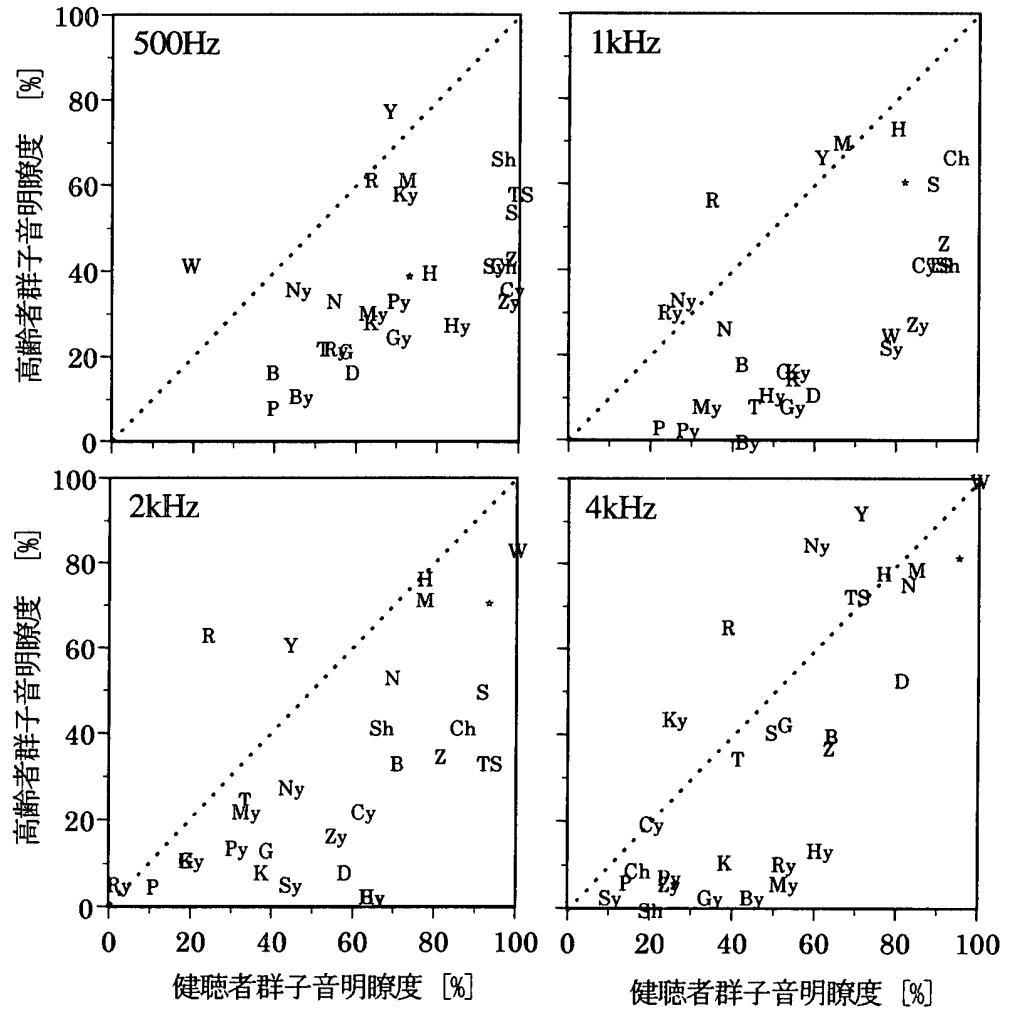

図 10 各帯域騒音付加音場における健聴者と高齢者の子音明瞭度の比較 (SN 比：-20dB)

\section{5. 文中の子音出現頻度による重み付け明瞭度}

通常の音節明瞭度は平等率音表を用いた際の全音節の平均的な值 である。しかし，文を受聴する観点からは，全音節が文中に等頻度 で出現しているわけではない。そこで, 文中の子音出現頻度により， 各子音に重み付けを行った明瞭度を算出し，音源の子音構成を考虑 した明瞭度評価を試みる。また, 5節に示した子音異聴について音節 
毎の重要性の違いも明らかにする。

\section{1 重み付け明瞭度の定義}

文中の子音をもつ音節の出現率で重み付けされた明暸度 $(A S W) を$ 式 (4) で定義する。

$$
A S w=\sum_{i=1}^{m} P A_{i} \cdot \frac{n_{c i}}{n_{p i}} \quad[\%] \quad \cdots(4)
$$

ただし，

$P A_{i}$ : 子音 $i$ 持つ音節の出現率 [\%]

$$
\sum_{i=1}^{m} P A_{i}=100
$$

$n_{c i}:$ 正聴した子音 $i$ 数

$n_{p i}:$ 提示した子音iの数

$m$ : 子音の種類数

なお，通常の明瞭度は式において

$P A i=100 \% \mathrm{~m}$ とした場合と同等とみ なせる。また，母音の異聴については取 り扱わず,「あ行」の母音のみの音節につ いては子音が付加されて受聴された場合 に子音を異聴したものとして扱う。

\section{2 重み付けに用いた子音出現率}

子音の出現率は，仙台市内の 9 つの公 共施設で用意されている非常放送文の子 音出現率の平均值を用いた。表 3 に音節 の出現率を示す。なお，集計に用いた音 節の総数は 3083 音節である。出現率に関 しては飯田 ${ }^{14)}$ や山田クによる調査結果と 大きな差はない。

\section{3 子音異聴率と子音出現率の関係}

5 節の結果より求めた子音の異聴率と 非常放送文中の子音出現の関係を，健聴 者群と高齢者群に分け， $4 \mathrm{kHz} \cdot \mathrm{SN}$ 比一 $20 \mathrm{~dB}$ の条件についてそれぞれ図11，図 12 に示す。図中の太字で示された音節は， 重み付け明瞭度中の誤答の $80 \%$ を占める 音節である。これより，健聴者と高齢者 で差が大きかった拗音の異聴が，拗音の

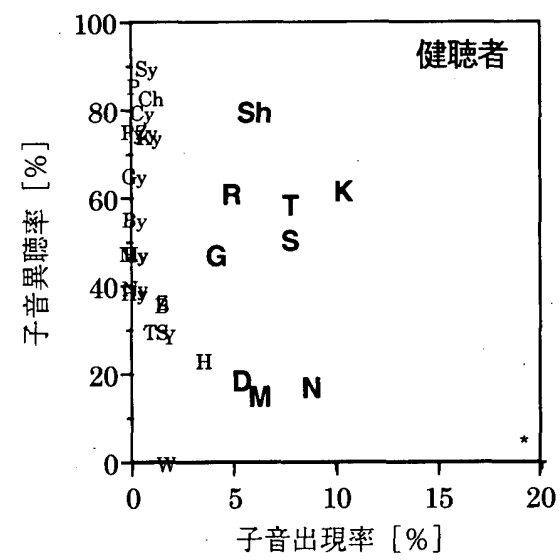

図 11 子音出現率と子音異聴率の関係 (健聴者 : $4 \mathrm{kHz}, \mathrm{SN}$ 比 $=-20 \mathrm{~dB}$ )
表 3 非常放送文における各子音出現率 [\%]

\begin{tabular}{crcr}
\hline \hline 子音 & 出現率 & 子音 & \multicolumn{1}{c}{ 出現率 } \\
\hline *(旺) & 19.20 & $\mathrm{Y}$ & 1.75 \\
$\mathrm{~B}$ & 1.39 & $\mathrm{By}$ & 0.03 \\
$\mathrm{G}$ & 4.09 & $\mathrm{~Gy}$ & 0.03 \\
$\mathrm{D}$ & 5.32 & $\mathrm{Ry}$ & 0.06 \\
$\mathrm{R}$ & 4.83 & $\mathrm{Zy}$ & 0.68 \\
$\mathrm{Z}$ & 1.43 & $\mathrm{Sy}$ & 0.68 \\
$\mathrm{~S}$ & 7.75 & $\mathrm{Hy}$ & 0.00 \\
$\mathrm{Sh}$ & 6.00 & $\mathrm{Py}$ & 0.00 \\
$\mathrm{H}$ & 3.47 & $\mathrm{Ky}$ & 0.81 \\
$\mathrm{P}$ & 0.06 & $\mathrm{Cy}$ & 0.42 \\
$\mathrm{~K}$ & 10.35 & $\mathrm{My}$ & 0.00 \\
$\mathrm{~T}$ & 7.72 & $\mathrm{Ny}$ & 0.03 \\
$\mathrm{Ch}$ & 0.88 & & \\
$\mathrm{TS}$ & 1.14 & $\mathrm{NN}$ & 5.25 \\
$\mathrm{M}$ & 6.26 & & \\
$\mathrm{~N}$ & 8.76 & & \\
$\mathrm{~W}$ & 1.62 & & \\
\hline \hline
\end{tabular}

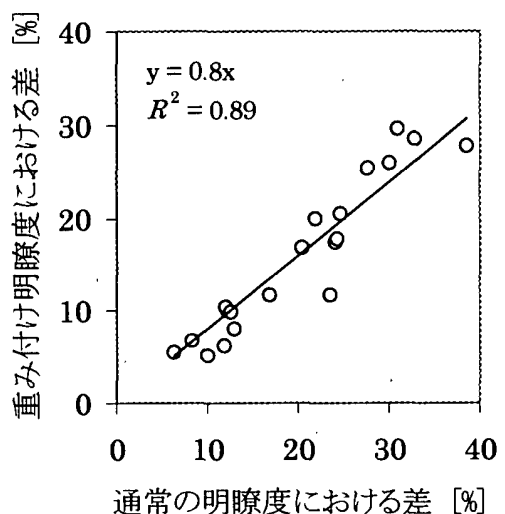

図 14 通常の明瞭度 (AS) と重み付け明 瞭度 $(\mathrm{ASw})$ における健聴者と高 齢者との差の比較

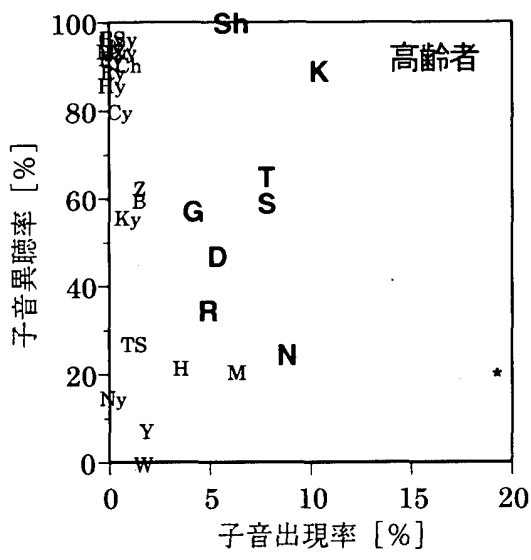

図 12 子音出現率と子音異聴率の関係 (高齢者： $4 \mathrm{kHz}, \mathrm{SN}$ 比 $=-20 \mathrm{~dB}$ )
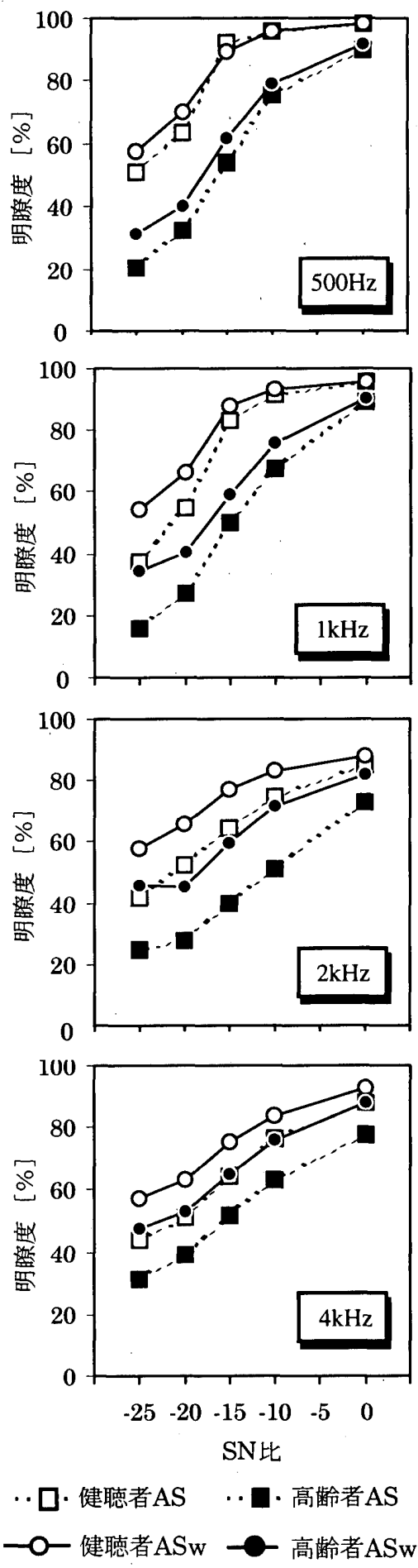

図 13 各帯域騒音付加音場に扔ける通常 の明瞭度 (AS) と重み付き明瞭度 (ASw) の比較 
は異聴が起こりやすい拗音の出現率が小さいことによる。母音の異 聴の割合が大きい $500 \mathrm{~Hz}$ 带域騒音付加音場においてはASと ASwの 差は小さい。それとは対照的に，子音の異聴の割合が大きい $2 \mathrm{kHz}$, $4 \mathrm{kHz}$ 帯域騒音付加音場においては AS と ASwの差が大きくなる。

健聴者と高齢者の AS と ASwの差を検討するため, 健聴者の明瞭 度から高齢者の明瞭度を差し引いた值について, AS と ASw との関 係を図 14 に示す。これより，健聴者と高齢者の明瞭度の差について， 重み付け明暸度は通常の明瞭度の約 $80 \%$ となり, 健聴者と高齢者の 差が小さくなる傾向がある。これは通常の平等率音表による明瞭度 が，高齢者が異聴しやすい抝音の影響を大きく受けているためであ り，音源特性を考慮した場合，通常の平等率音表による明暸度は明 瞭度の低下を大きく見積もる可能性がある。

以上から，子音が異聴しやすい帯域の騒音が卓越している音場に おいては, 通常の明瞭度は騒音が音声伝達に及ほす影響を大きく評 価している可能性があり，音源の特性を考慮した場合，音声情報は 高齢者について通常の明瞭度により評価される場合よりも健聴者と の差が小さくなる場合があるといえる。

\section{6. まとめ}

本研究により，以下のことが明らかとなった。

(1) 高齢者が健聴者と同程度の明瞭度を得るには, SN 比において 5 10dBAの改善が必要である。

(2) 被験者間の聴力のばらつき及び健聴者と高齡者の聴力差が小さ い低い周波数帯域が騒音により妨害された場合, 音節の受聴は 被験者間のばらつきが大きく, 聴力損失の程度も大きい高い周 波数域の聴力に依存する。

(3) 明瞭度指数による音声伝達性能評価の際には, シフト因子 S の 調整により加齢による聴力損失を考虑できる。

(4) 健聴者と高齢者の異聴傾向の比較を行い, それぞれの特徵を明 らかにした。

(5) 文中の子音出現頻度による重み付け明瞭度を用い文を受聴する 際に重要となる子音を抽出した。

（6) 重みづけ明瞭度により音声情報伝達品質を評価した場合，高齢 者と健聴者の明瞭度の差が通常の明瞭度より $20 \%$ 程度小さくな ることを示し，文章聴取の観点から，平等率音表による通常の 明瞭度は騒音場における聴力損失の影響を大きく評価している ことを示した。

文章聴取という観点からは, 文章了解度の検討が必要となり，子 音のみならず音節, 単語, 文の構成といった要因が音声情報伝達に 及注す影響を明らかにする必要がある。

\section{謝辞}

本研究を進めるにあたり，被験者として仙台市シルバー人材セン ターの御協力を得た。また鹿島建設 (株) 技術研究所に機材等のご援 助を受けた。ここに厚く感謝の意を表す。

本論文は文部省科学研究費補助金 (平成 $1 \sim 3$ 年度, 課題番号 01460196 一般研究 (B) 研究代表者：長友宗重,及び平成 6 年度,課 題番号 06750620 奖励研究 (A) 研究代表者：佐藤洋)，ならびに鹿島 学術振興財団研究助成金によって実施された研究の一部である。 注

1） 2 節の実験音場においては聴取上のラウドネスを考慮し，騒音 レベルをdBAで定義したが, 本検討では全帯域騒音を扱う上で SN比を定義しなければならないので, 精度上 $\mathrm{dBC}$ で定義した。

2) 明瞭度を提示した音節に対する正聴した音節の割合ととらえ， これを子音について拡大解釈したものを本報では子音明瞭度と
呼ぶ。

3）本論文は参考文献 15）～22）を加筆·修正し，まとめたものであ る。

参考文献

1) ANSI S3.5-1969: Methods for the calculation of the articulation index American National Standards Institute, New York (1969)

2) Chaslav V. Pavlovic : Use of the articuration index for assessing residual auditory function in listers with sensorineural hearing impairment, J.Acoust.Soc.Am., 75 (4) ,pp.1253-1258, 1984

3) Chaslav V. Pavlovic : An articulation index based procedure for predicting the speech recognition performance of hearingimpaired individuals, J.Acoust.Soc.Am., 80 (1) , pp.50-57, 1986

4) 坂田展甫、吉田拓正、德山久雄、春田千秋、大鶴 徹 : 騒音場 における音声伝達の特性解析 一明瞭度と損失情報量による受 聴系の基礎解析一，日本建築学会論文報告集，No.276,pp.7986,1979

5)落合博明, 牧野康一, 山田一郎, 館野誠, 村瀬真理子：環境騒音 下での言葉の明瞭度に関する基礎的研究 (2)，日本音響学会講 演論文集,pp.473-474, 1995.9

6) 飯田重隆：建築空間における明瞭度研究について,日本音響学 会第 1 回シンポジウム「試験用音声の標準化」,pp.1-9, 1985.6

7）山田由紀子：明暸度試験における異聴の傾向と日本語の了解度 ,明治大学科学技術研究所紀要, Vol.14, No.10, 1975

8) 明瞭度標準テープ (1965) の制作過程ならびに取り扱い要領に ついて，日本音響学会明瞭度委員会，1965

9) 単音節明瞭度テープ [解説]，日本音響コンサルタント協会, 1979

10) ISO 7029-1984 (E): Threshold of hearing by airconduction as a function of age and sex for otologically normal persons

11) T.Houtgast \& H.J.M.Steeneken : The Moduration Transfer Function in Room Acoustics as a Predictor of Speech Intelligibility, Acustica, 28, pp.66-73, 1973

12）小椋靖夫, 浜田晴夫,三浦種敏：音場における音声伝送品質のた めMTF と STIについて, 日本音響学会誌, 40 巻 3 号, pp.181. 191,1984

13）三浦種敏：日本語に対する定量的な伝送品質と伝送特性との関 係, 日本電信電話公社,研究実用化報告,第 3 巻第 4 号, pp.468501,1954

14) 飯田重隆 : 明瞭度テストにおける異聴の傾向,日本音響学会誌 , 29 (9) ,pp.527-534,1973

15）長友宗重, 佐藤克久:音声伝達における聴力損失の影響に関する 研究 その 2 各帯域騷音場に扔ける単音節明暸度, 日本建築 学会大会学術講演梗概集, pp.375-376, 1989.10

16) 嶋田泰平, 長友宗重, 田原 誠:音声伝達における聴力損失の影 響に関する研究一その 3 騒音帯域及び SN 比と単音節明瞭度一 , 日本建築学会大会学術講演梗概集, pp.271-272, 1990.10

17）田原 誠, 長友宗重:音声伝達における聴力損失の影響に関する 研究一その 4 帯域 SN 比及び AI と単音節明瞭度一, 日本建築学 会大会学術講演梗概集, pp.345-346, 1991.9

18）長友宗重, 嶋田泰平, 田原 誠, 佐藤 洋: 聴力損失のある高齢 者の各種音場における聴取明瞭度，日本機械学会第 1 回環境工 学シンポジウム' 91 講演論文集, pp.418-422, 1991.7

19）佐藤 洋, 長友宗重：音声情報伝達における聴取条件の影響と 評価方法に関する研究 - 残響付加音場における無意味三連音節 明瞭度試験 -, 日本建築学会大会学術講演梗概集, pp.343-344, 1991.9

20) 佐藤 洋, 長友宗重 : 各種音場における高齢者の音節受聴特性 日本音響学会建築音響研究会資料, 資料番号AA93-48, 1993.10

21) Hiroshi SATO, Muneshige NAGATOMO, Hiroshi YOSHINO : INVESTIGATION ON PARAMETERS OF ARTICULATION INDEX FOR HEARING IMPARMENT IN NOISE FIELDS,Proceedings of INTER NOISE 94, pp.1855-1858, 1994.8

22）佐藤 洋, 長友宗重, 吉野 博: 文章中の音節出現頻度を考慮し た無意味三連音節明瞭度, 日本音響学会講演論文集, pp.795$796,1995.9$

(1996年6月10日原稿受理，1996年11月27日採用決定） 